\title{
ARTEFAK KOLONIAL PERKEBUNAN PANGLEJAR, MASWATI, RAJAMANDALA MASA HINDIA BELANDA: ARTI DAN ARAH SEJARAH
}

\section{Colonial Artifacts of Plantation of Panglejar, Maswati, and Rajamandala in Nederlandsch-Indie Era: Meaning and Direction of History}

\author{
Lia Nuralia \\ Balai Arkeologi Jawa Barat \\ Jalan Raya Cinunuk Km. 17, Cileunyi, Bandung \\ E-mail: liabalar@yahoo.com \\ Naskah diterima: 9 Juni 2020 - Revisi terakhir: 24 September 2020 \\ Disetujui terbit: 24 September 2020 - Tersedia secara online: 28 September 2020
}

\begin{abstract}
Colonial plantation artifacts are an important cultural in the history of plantation at Bandung, West Java. What and how the plantation artifacts are the main problem in this paper. the purpose of this paper is to explain the colonial plantation artifacts in the form of inscriptions and old maps of the garden. The method used is a desk research on archeological research reports, books, and the internet. The data sources obtained are the inscription of the establishment of the old Panglejar tea factory in the IHT Building, the inscription of the establishment of the Administrator of Maswati Plantation house in the Pusdiklat Building, and the old map of the Rajamandala $P$ lantation in the Office of Rajamandala Afdeling 1 of Pnaglejar Platation. The three colonial artifacts give special meaning to the continuity of plantation history since the days of the Dutch East Indies until now, as well as showing directions to search for and find historical information through colonial archival research and information from interviews with relevant informants at the present time.
\end{abstract}

Keywords: Plantation Artifacts, Panglejar, Maswati, Rajamandala, Meaning and Direction of History

\begin{abstract}
Abstrak
Artefak kolonial perkebunan merupakan jejak budaya penting dalam sejarah perkebunan di Bandung Jawa Barat. Apa dan bagaimana artefak perkebunan tersebut menjadi permasalahan pokok dalam tulisan ini. Tujuan tulisan ini adalah menjelaskan artefak kolonial perkebunan berupa prasasti dan peta lama kebun. Metode yang digunakan adalah desk research terhadap artefak perkebunan dalam laporan hasil penelitian arkeologi tahun 2018, dilengkapi pendukung penjelasan dari buku dan internet. Artefak kolonial perkebunan yang dikaji dalam tulisan ini, yaitu prasasti pendirian pabrik teh Panglejar lama di Gedung IHT Bagian Panglejar, prasasti pendirian rumah Administratur Kebun Maswati di Gedung Pusdiklat Panglejar, dan peta lama Kebun Rajamandala di Kantor Afdeling Rajamandala 1 Perkebunan Panglejar. Ketiga artefak kolonial tersebut memberi arti dalam kesinambungan sejarah perkebunan sejak zaman Hindia Belanda sampai sekarang, serta menunjukkan arah untuk mencari dan menemukan kelengkapan informasi kesejarahan melalui penelitian arsip kolonial dan informasi hasil wawancara dengan informan terkait di masa kini.
\end{abstract}

Kata Kunci: Artefak Perkebunan, Panglejar, Maswati, Rajamandala, Arti dan Arah Sejarah. 


\section{PENDAHULUAN}

Keberadaan perkebunan besar era Hindia Belanda menjadi jejak budaya penting dalam perjalanan panjang sejarah perekonomian Indonesia, sebagai bukti kemakmuran Hindia Belanda dan negeri induk Belanda ketika itu (O’Malley, 1988: 197). Perkebunan besar terutama milik swasta asing di Hindia Belanda, mencapai puncak kejayaan pada akhir abad ke-19 awal hingga abad ke-20, atau periode 1870-1942. Komoditas perkebunan penting dari tanah Jawa yang berorientasi ekspor, seperti gula, kopi, teh, karet, kina, dan kelapa, terutama produksi teh dan karet mengalami peningkatan produksi yang menonjol di awal abad ke-20 (Kartodirdjo \& Surjo, 1991: 93). Jejak kejayaan perkebunan besar tersebut salah satunya berupa artefak perkebunan.

Artefak perkebunan adalah objek arkeologis yang ditemukan di lokasi perkebunan warisan Belanda, sebagai benda budaya (material culture) bernilai sejarah. Artefak atau artifact adalah an object, such as a tool, that was made in the past (Cambridge Dictionary, n.d.). Artefak memiliki ciri-ciri umum, yaitu: dibuat langsung dan dapat dipindahkan (movable) oleh manusia, tanpa merusak bendanya. Bahan dasar artefak terbuat dari berbagai material, dengan berbagai macam ukuran, selama masih dapat dibawa oleh manusia (Pusat Penelitian Arkeologi Nasional, 2008: 39-40).

Berdasarkan pengertian artefak tersebut, tinggalan budaya benda pada masa Hindia Belanda di perkebunan, yang dapat dipindah atau dibawa langsung disebut artefak kolonial perkebunan. Benda budaya berupa artefak perkebunan merupakan material culture sekaligus immaterial culture. Sebagai material culture dapat dikategorikan bentuk (form), fungsi (function), dan ruang budayanya (spatial). Sebagai immaterial culture memberi informasi kesejarahan melalui makna yang terkadung dibalik wujud fisiknya dilengkapi dengan informasi dari arsip kolonial.

Salah satu perkebunan warisan zaman Belanda yang memiliki artefak kolonial perkebunan adalah Perkebunan Panglejar. Perkebunan Panglejar secara administratif sekarang termasuk ke dalam wilayah Kecamatan Cikalong Wetan dan Kecamatan Cipatat, Kabupaten Bandung Barat, Provinsi Jawa Barat (Gambar 1).
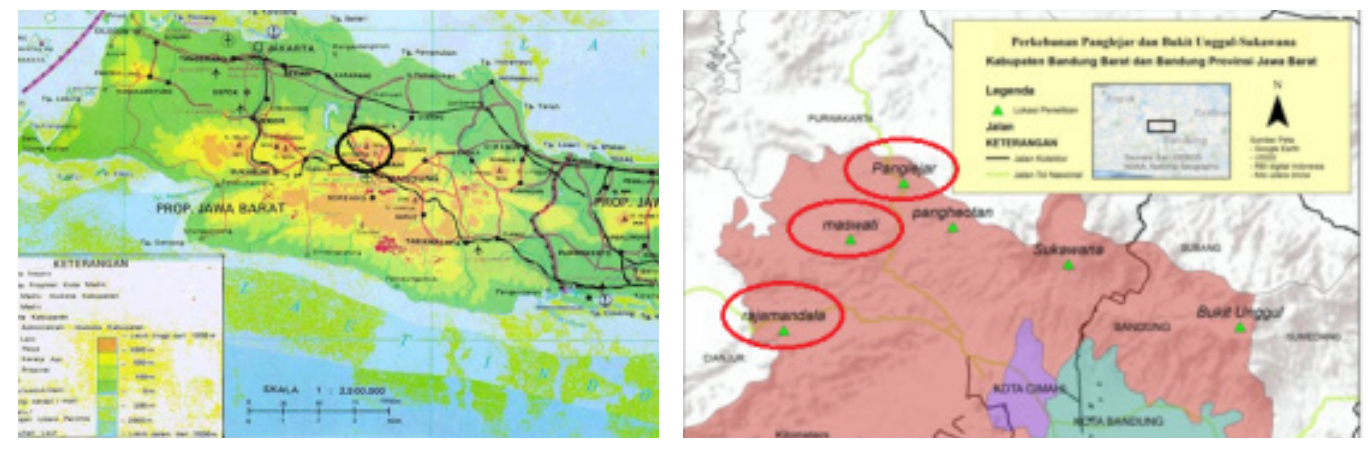

Gambar 1. Lokasi Perkebunan Panglejar, Maswati, Rajamndala dalam Peta Wilayah Provinsi Jawa Barat dan Wilayah Kabupaten Bandung Barat (Sumber: Laporan Penelitian Arkeologi 2018).

Pada tahun 2018 ketika dilakukan penelitian lapangan, sampai tahun 2020 ini, Perkebunan Panglejar PTPN VIII merupakan gabungan dari enam kebun, yaitu Panglejar lama, Pangheotan, Friesland, Maswati, Gunung Susuruh, dan Rajamandala, yang sekarang sudah menjadi bagian kebun atau afdeeling (afdeling). Tiga bagian kebun di antaranya menjadi lokasi kajian dalam tulisan ini, yaitu Afdeling Panglejar 1A, Afdeling Maswati 2, dan Afdeling Rajamandala 1. Kebun Panglejar sudah tercatat dalam registrasi 
Pemerintah Hindia Belanda sejak tahun 1893, Kebun Maswati sejak tahun 1899, dan Kebun Rajamandala sudah berdiri sejak tahun 1898 (Regeering Alamanaks voor Nederlandsch-Indie, 1901; 1902) meninggalkan jejak sejarah berupa artefak perkebunan. Artefak kolonial Perkebunan Panglejar berupa prasasti dipahatkan di Gedung IHT Panglejar berangka tahun 1925. Kemudian artefak kolonial Perkebunan Maswati juga berupa prasasti, yang dipahatkan di Gedung Pusdiklat Teh Perkebunan Panglejar berangka tahun 1927. Selanjutnya di Kebun Rajamandala, artefak kolonial berupa peta lama Kebun dan Emplasemen Rajamandala, tanpa angka tahun (Nuralia, 2018). Keberadaan artefak kolonial perkebunan tersebut menunjukkan satu proses perjalanan penting bagi sejarah perkebunan di Jawa Barat secara umum. Oleh karena itu, permasalahan pokok dalam tulisan ini adalah apa dan bagaimana artefak kolonial perkebunan sebagai tinggalan budaya benda, dapat memberi arti dan arah sejarah.

Pengertian arti dan arah sejarah dalam tulisan ini mengacu kepada arti atau makna yang tersurat dari keberadaan artefak kolonial perkebunan, sedangkan arah sejarah mengacu kepada sejarah perkebunan Panglejar khususnya, yang terkait dengan sejarah kolonialisme di Indoensia secara umum.

Tulisan ini berdasarkan hasil penelitian arkeologi industri tahun 2018, yang salah satu hasil temuannya berupa artefak. Kajian artefak kolonial perkebunan termasuk kajian arkeologi industri (industrial archaeology) (Cassela, 2005: 15), dengan framework: surface surveys, excavations, archival research; dan oral history interviews (Palmer, 2005: 15). Metode penelitian dalam penelitian arkeologi tersebut adalah Metode Penelitian Arkeologi, sedangkan tulisan ini memakai Desk Research dengan analisis wujud fisik artefak dan kesejarahan, dengan tahapan analisis sebagai berikut.

1. Menentukan artefak perkebunan yang akan dikaji;

2. Menggambar, mendeskripsikan, dan menterjemahkan inskripsi artefak;

3. Mencari arsip kolonial yang terkait dengan artefak perkebunan tersebut;

4. Melakukan analisis dan interpretasi terhadap isi arsip dan mengkaitkannya dengan artefak.

\section{HASIL DAN PEMBAHASAN}

\section{Prasasti Kolonial Perkebunan Panglejar}

Prasasti Kolonial Gedung Industri Hilir Teh (IHT) selanjutnya disebut Prasasti Kolonial Perkebunan Panglejar, adalah prasasti pendirian kembali Pabrik Teh Panglejar lama. Prasasti tersebut dipahatkan di dinding dalam ruang kantor administrasi Gedung IHT PTPN VIII Bagian Panglejar ${ }^{1}$. Gedung IHT tersebut (Gambar 2) merupakan bekas pabrik teh Kebun Panglejar lama, juga pernah digunakan sebagai pabrik karet Ribbed Smoked Sheet (RSS). Bekas bangunan Kamar Asap (rubberfabriek) masih ada dan sekarang ini digunakan sebagai gudang. Lokasi gedung IHT terletak di emplasemen Kebun Panglejar lama (Panglejar 1A).

Perkebunan Panglejar lama atau Onderneming Pangledjar menurut Hans Boers ${ }^{2}$

\footnotetext{
${ }^{1}$ Wawancara dengan Ismail, Kepala Bagian Produksi IHT PTPN VIII Panglejar (Panglejar, 5 Maret 2020)

${ }^{2}$ Hans Boers adalah Historian Pemakaman Kuno Belanda serta co-Worker Arsip Isfaham Iran dan Arsip Armenia. Ia adalah seorang peranakan/Indo-Belanda, dengan ayah Belanda dan ibu Madura/Indonesia. Ayah dan pamannya pernah bekerja di Perkebunan Sukawana tahun 1911-1928. Ia juga pernah tinggal di
} 
adalah perusahaan keluarga, yang bernama Boutmij Thee Cultuur NV, Daniel Cornelis Boutmij (D.C. Boutmij atau Boutmy), sebagai pendiri awal dan pemilik utama ("Inventaris van het archief van het Fonds/Belindo: Thee cultuur maatschappaij Pangheotan een Diverse Andere Cultuur maatschappijen, 1894-1875, Door J.A.A.Bervoets," 1994: 5-11) ${ }^{3}$. Kemudian perusahaan perkebunan tersebut berpindah kepemilikan menjadi milik N.V. Cult. Mij. Pangledjar Djakarta. Lokasi kebun terletak $\pm 10 \mathrm{Km}$ dari halte Sasaksaat dan Rendeh, pinggir jalan raya Bandung-Purwakarta menuju Jakarta (Ismet, 1970).

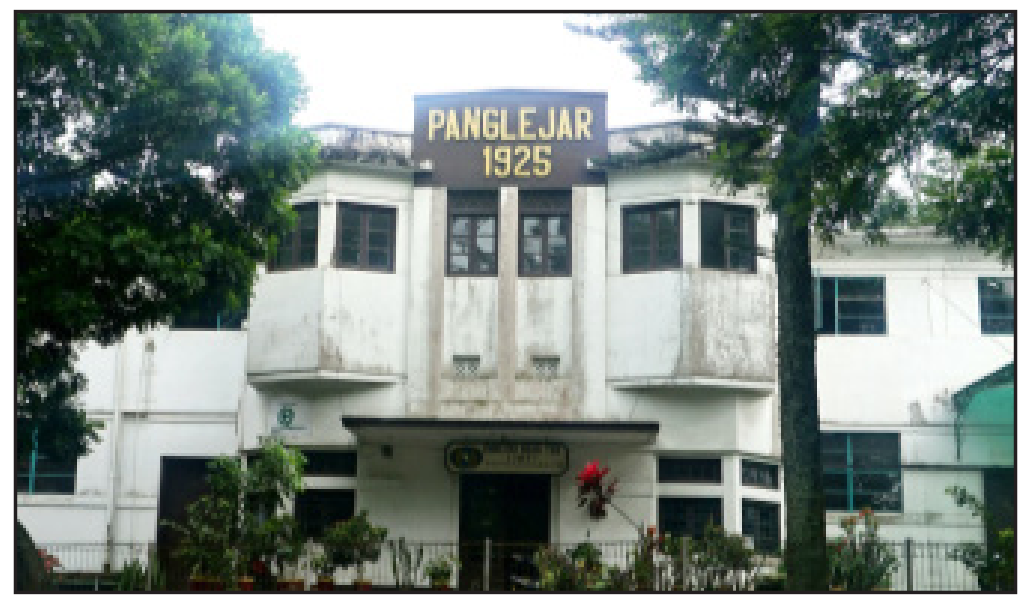

Gambar 2. Gedung IHT 1925 PTPN VIII Bagian Panglejar (Sumber: Dokumen Balai Arkeologi Jawa Barat, 2018).

Perkebunan Panglejar lama memiliki lokasi permukiman disebut Emplasemen Permukiman Panglejar. Emplasemen Panglejar lama tersebut sekarang menjadi Panglejar 1A dan Panglejar 1B Perkebunan Panglejar (Gambar 3 dan 4). Secara administratif lokasi emplasemen permukiman tersebut sekarang termasuk ke Desa Cisomang Barat dan Desa Tenjo Laut. Gedung IHT sendiri terletak di Desa Tenjo Laut, di lahan perbatasan antara Desa Tenjo Laut dan Desa Cisomang Barat, Kecamatan Cikalong Wetan, Kabupaten Bandung Barat, Provinsi Jawa Barat (Nuralia, dkk, 2018).

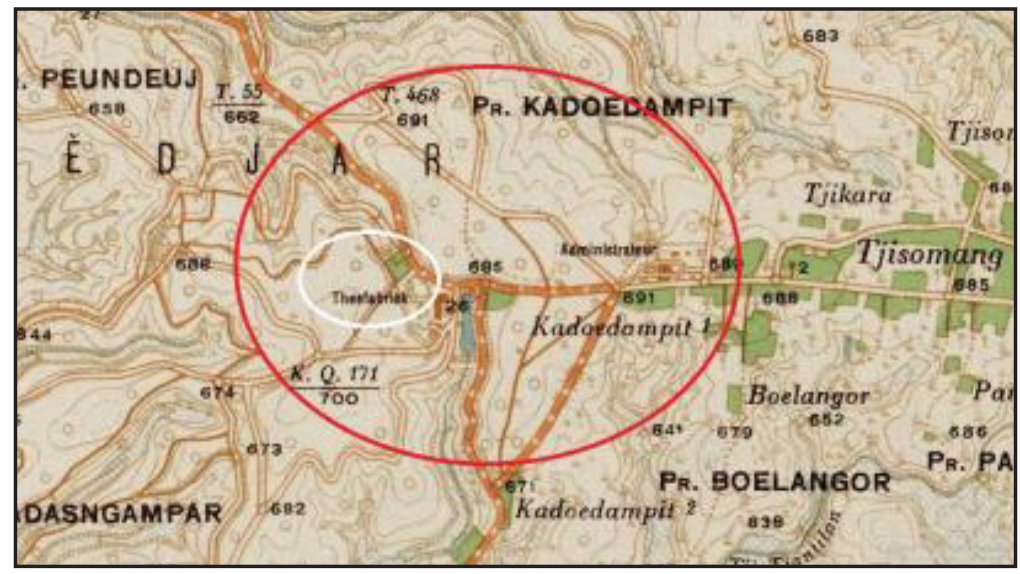

Gambar 3. Letak Emplasemen Kebun Panglejar dalam Peta Topografi lama (Sumber: Peta topografi Blad 31 d JAVA Resn Batavia en Pr. Regentschappen 1918. Dutch Colonial Maps, Leiden University Library. Laporan Penelitian Arkeologi 2018).

Indonesia (Madura dan Surabaya) dan sekarang menetap di Belanda.

${ }^{3}$ Arsip berbahasa Belanda hasil pencarian di Arsip Negeri Belanda di Den Haag dan diterjemahkan secara bebas oleh Hans Boers tahun 2017. 


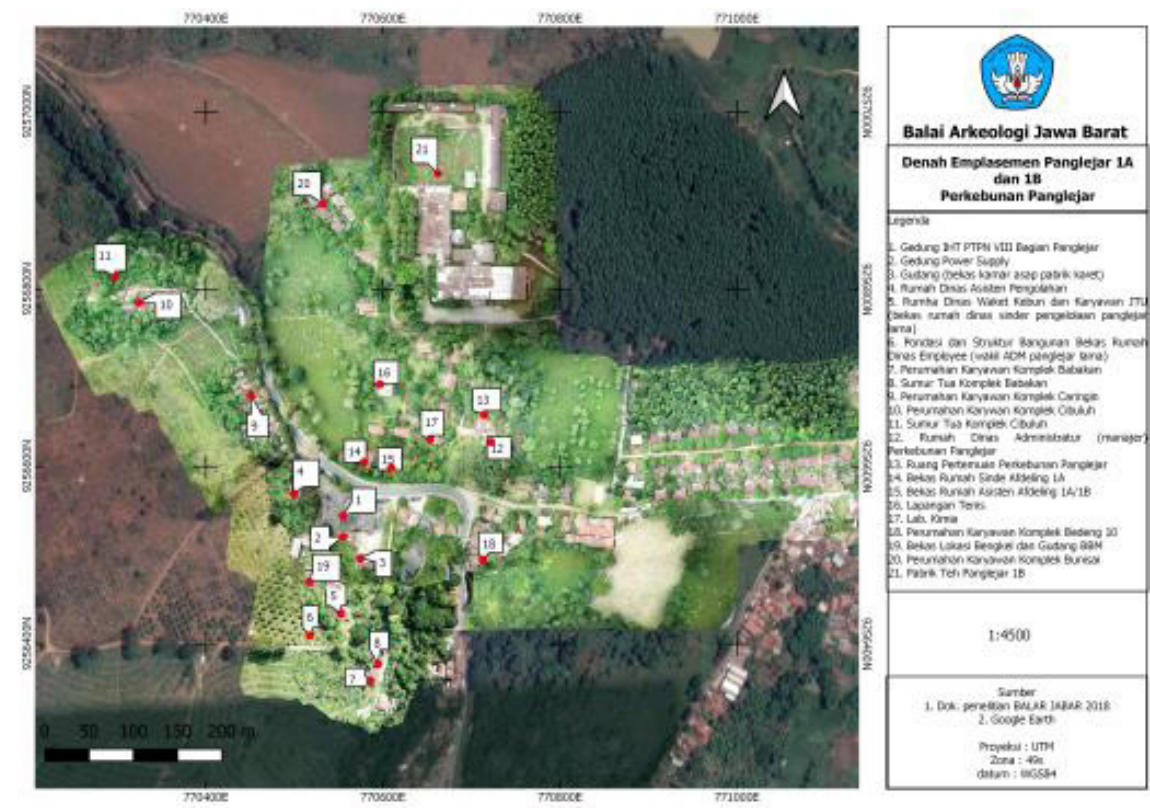

Gambar 4. Lokasi Artefak Kolonial Perkebunan Panglejar di Dalam Gedung IHT Bagian Panglejar (Nomor 1) (Sumber: Dokumentasi Penelitian Arkeologi 2018. Modifikasi Lia Nuralia dan Azhar Rachman, 2020).

Keberadaan Prasasti Kolonial Perkebunan Panglejar baru diketahui bulan Maret tahun 2020. Manurut keterangan Ismail (kepala bagian produksi IHT Panglejar), selama ini keberadaan prasasti tidak diketahui karena tertutup papan kayu pelapis dinding. Ismail mendapat informasi dari sesepuh desa setempat, yaitu Kosim yang pernah menjadi mandor di IHT. Kemudian papan penutup tersebut dibongkar pada tanggal 3 Maret 2020 atas inisiatif Ismail sendiri. Dengan adanya pembongkaran ini maka prasasti yang sebelumnya tidak diketahui, dapat dilihat kembali.

Prasasti Kolonial Perkebunan Panglejar dipahatkan pada dinding ruangan dalam Gedung IHT Panglejar bertuliskan, "De eer ste steen voor deze pabriek werd gelegd door Marianne Jeannette van hillegondsberg. Den 24 maart 1925" (Gambar 5). Terjemahan bebasnya adalah "Peletakan batu pertama untuk mendirikan bangunan (pabrik) ini dilakukan oleh Marianne Jeanette van Hillegondsberg, tanggal 24 Maret 1925". Marianne Jeanette van Hillegondsberg adalah putri J.F. van Hillegondsberg, seorang Belanda yang ketika itu menjabat sebagai Administratur Kebun Panglejar lama ${ }^{4}$.

Jan Frederick van Hillegondsberg atau J.F. van Hillegondsberg (Gambar 6) menjadi Administratur Kebun Panglejar lama yang keempat, setelah dijabat keluarga Boutmy dan pengusaha Inggris ${ }^{5}$. Kepemilikan saham tidak lagi milik satu orang atau satu keluarga, tetapi berkembang menjadi perusahaan joint venture. Posisi administratur pun berganti, dan seorang Belanda yang bernama Jan Frederick van Hillegondsberg menjadi administratur ke-4 Panglejar. J.F. van Hillegondsberg yang lahir tahun 1890 adalah seorang pengusaha dalam bisnis perkebunan di Hindia Belanda. Kiprahnya di dunia

\footnotetext{
${ }^{4}$ Sumber: Kartu Penduduk keluarga Jan Frederik, istri dan anak Marianne, wawancara online dengan Arsiparis Hans Boers yang tinggal di Belanda (22, 23, 24 Maret 2020).

${ }^{5}$ ADM ke-1: Daniel Cornelis Boutmij; ADM ke-2 Charles Antoine Joseph Boutmy (anak Boutmij). Tahun 1910 Pabrik Teh dan Pabrik Karet Panglejar dijual kepada perusahaan Inggris, sehingga G.J. Eschauzier menjadi pemilik sekaligus pengelola (ADM ke- 3) ("Ministerie van Onderwijs, Cultuur en Wetenschap, Nummer Archiefinventaris: 2.20.37.11,”)
} 
bisnis perkebunan besar berakhir cukup tragis. Singkat cerita, ketika dia masih menjabat sebagai administratur Panglejar, di tahun 1942 ditangkap Pemerintah Pendudukan Jepang dan masuk kamp interniran Jepang di Surabaya, Jawa Timur. Kemudian di tahun 1944 dipindahkan ke Pekanbaru, Sumatera. Tidak lama kemudian ia meninggal dunia tanggal 9 Maret 1945, karena sakit malaria selama berada di kamp interniran. Selanjutnya ia dimakamkan di pemakaman Simpang Ampat Sumatera (Geplaatst door Coordinator Archief, Oorlogsgravenstichting op 12 Januari 2015).
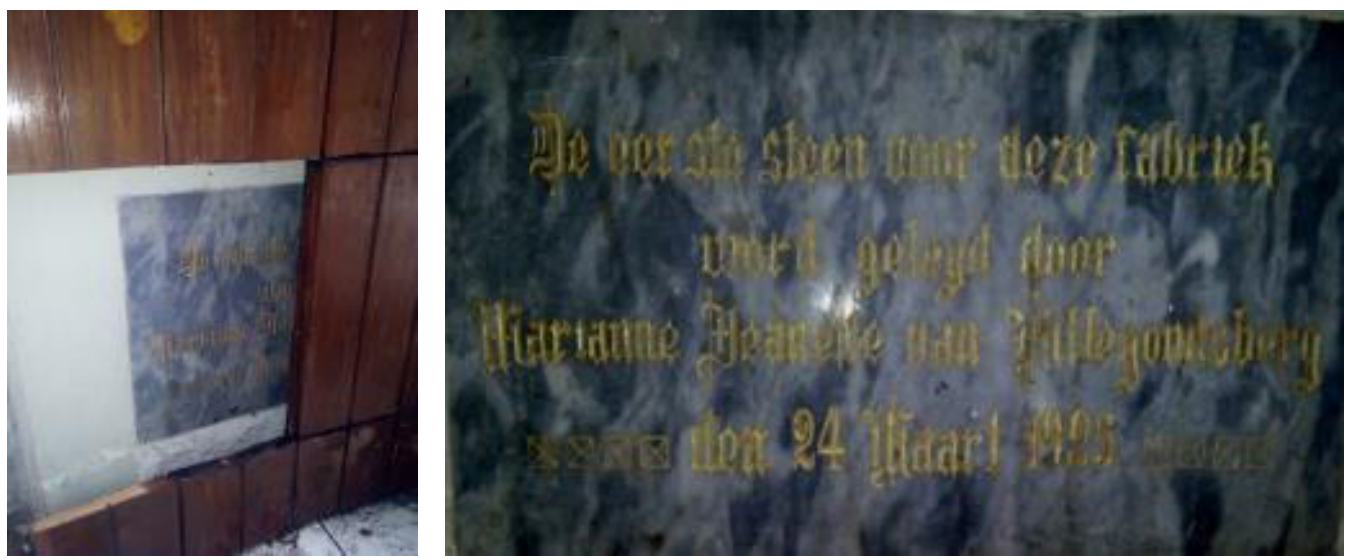

Gambar 5. Prasasti Kolonial Perkebunan Panglejar di Gedung IHT 1925 Panglejar (Sumber: Dokumen Kantor Adminstrasi IHT PTPN VIII Bagian Panglejar).

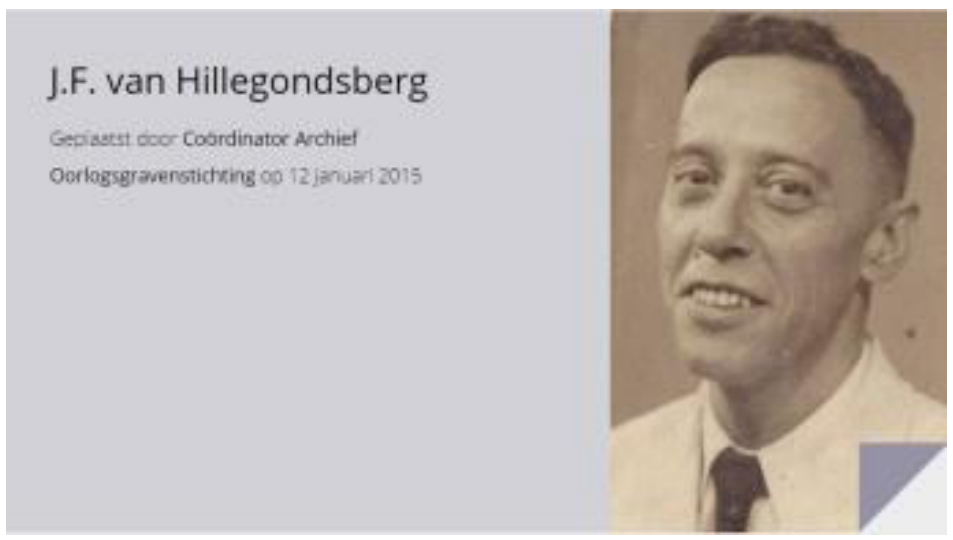

Gambar 6. Jan Frederick van Hillegondsberg, Administratur Kebun Panglejar lama ke-4 (Sumber: Geplaatst door Coordinator Archief, Oorlogsgravenstichting op 12 Januari 2015; Hans Boers 2020).

Perusahaan Perkebunan Panglejar yang telah berdiri sejak tahun 1893, dengan produksi teh dan karet (Inventaris van het archief, No. 094f, Inventaris No: 4577. Dossier: 4322. Organisatie: NIOD Onstituut Voor Oorlogs-, Holocaust-en Genocidestudies: 40). Pada tahun 1910 Pabrik teh dan karet Panglejar dijual kepada perusahaan Inggris, dengan harga 1.118.000,- English Pound Sterling ("Persoonlijkheden In Het Koninkrijk Der Nederlanden In Woord en Beeld. Nederlanders en Hun Werk, Door DR. N. Japikse," 1938: $220)^{6}$. Keberadaan Perkebunan Panglejar tidak lepas dari nama besar Daniel Cornelis Boutmij atau D.C. Boutmij (Boutmy), pengusaha terkemuka tahun 1890-an, Pemillik awal Boutmij Thee Cultuur NV. Pada tahun 1894, Charles Antoine Joseph Boutmy (anak

\footnotetext{
${ }^{6}$ Naskah arsip ini diperoleh di Arsip Negeri Belanda di Den Haag dan diterjemahkan atas bantuan Hans Boers, 2017.
} 
D.C. Boutmij) diangkat menjadi administratur Perkebunan Panglejar (Nuralia, dkk, 2018). Kebun Panglejar terdiri dari Panglejar I - IV, didirikan antara tahun 1893-1898, seperti tercatat dalam Arsip Kolonial sebagai berikut.

Districten Radjamandala, Porceelen Pangledjar I-VI, Cultuurmaatschappij "Pangledjar", o., D.C. Boutmy, a., ondernemers en erkende administrateur G.J. Eschauzier, o., E.H. Verstege, a., Uitgestrektheid van de porceelen in bouws (500 vierkante roeden) 504, 92, 4, 3, 245, 22; Datum van inschrijving van het erfpachtsrecht in the openbare registers 28 Juni 1893, 28 Juni 1893, 2 April 1897, 2 April 1897, 2 April 1897, 19 April 1898, Aard der geteelde production Koffie (Regeering Alamanaks voor Nederlandsch-Indie, 1893: 518-519).

Pada zaman Pendudukan Jepang, Pabrik Karet dan Pabrik Teh Panglejar dibakar tentara Jepang. Akan tetapi, pabrik selamat dari kehancuran, hanya mengalami kerusakan sedikit dikarenakan kekokohan bangunannya (Wardini et al., 2010: 83). Pada masa Pemerintahan Republik Indonesia, di tahun 1948 pabrik teh konvensional tersebut diganti dengan mesin listrik (Inventaris van het archief, No. 094f, Inventaris No: 4577. Dossier: 4322. Organisatie: NIOD Onstituut Voor Oorlogs-, Holocaust-en Genocidestudies: 40). Akan tetapi, sampai tahun 1957/1958 ketika terjadi "Nasionalisasi Perusahaan-perusahaan Asing”, produksi semakin menurun dan perlahan-lahan mengahadapi kerugian besar atau kehancuran masa-masa kejayaan produksi teh. Kemudian Pemerintah Republik Indonesia berusaha mengatasi kerugian dengan efisiensi perusahaan. Kebun Panglejar terus menerus mengalami perombakan afdeling dengan melakukan merger (Nuralia, dkk, 2018).

\section{Prasasti Kolonial Perkebunan Maswati}

Prasasti Kolonial Perkebunan Maswati adalah prasasti pendirian Rumah Administratur (ADM) Perkebunan Maswati. Rumah ADM telah beralih fungsi menjadi Gedung Pusat Pendidikan dan Pelatihan Teh Perkebunan Panglejar (2018) (Pusdiklat) ${ }^{7}$. Prasasti tersebut menempel di dinding depan Gedung Pusdiklat ${ }^{8}$ di emplasemen lama Onderneming Maswati (Gambar 7), milik N.V. Cult. Mij. Maswati Amsterdam, $\pm 1 \mathrm{~km}$ dari Halte Maswati dengan komoditas karet dan teh (Ismet, 1970).

\footnotetext{
${ }^{7}$ Gedung Pusdiklat sudah tidak difungsikan lagi, terkait proyek Kereta Cepat Indonesia-Cina (KCIC) dan Transit Oriented Development (TOD) Kota Baru Walini (wawancara dengan Iwan Rustandi, Asisten Afdeling Kebun Maswati 2, Panglejar 5 Maret 2020).

${ }^{8}$ Wawancara dengan Agus Sopandi, Petugas Bagian Umum Perkebunan Panglejar dan Ayi Rukmana, Petugas Tanaman Perkebunan Panglejar (Panglejar, April 2018).
} 


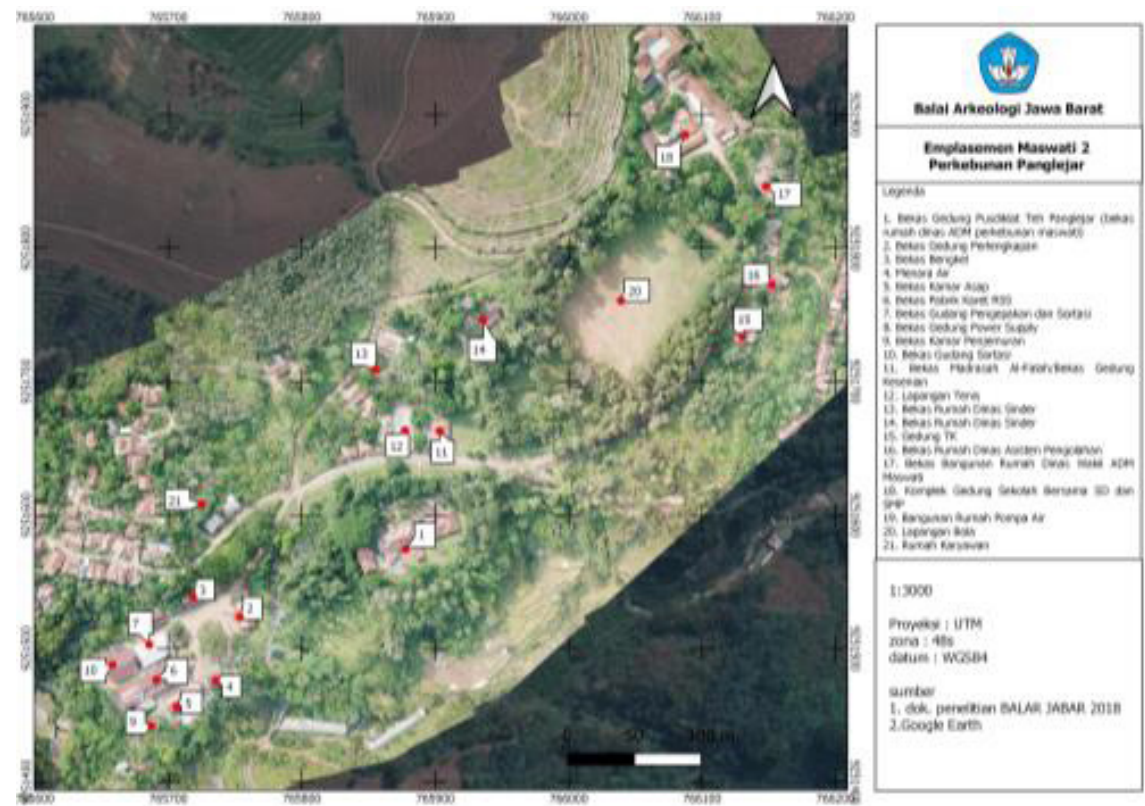

Gambar 7. Lokasi Artefak Kolonial Perkebunan Maswati di Gedung Pusdiklat Teh Panglejar Bagian Maswati (1) (Sumber: Dokumen Penelitian 2018. Modifikasi Lia Nuralia dan Azhar Rachman, 2020).

Pada tahun 2018, lokasi Gedung Pusdiklat termasuk ke dalam Emplasemen Maswati 2 Perkebunan Panglejar (Gambar 8), di Desa Kanangasari, Kecamatan Cikalong Wetan, Kabupaten Bandung Barat (Nuralia, dkk, 2018). Prasasti Kolonial Rumah Administratur Maswati dipahatkan di bagian dinding muka rumah, dekat pintu masuk utama, di sebelah kanan pintu (Gambar 9). Tulisan yang dipahatkan dalam prasasti adalah: "Eerste Steen Gelegd Door Carel Ditlov Brix 5 September 1927”, dan diterjemahkan secara bebas, yaitu: "Peletakan batu pertama oleh Carel Ditlov Brix pada tanggal 5 September 1927". Kebun Maswati atau Onderneming Maswati, milik perusahaan Belanda bernama N.V. Cult. Mij. Maswati Amsterdam, lokasi kebun terletak $\pm 1 \mathrm{Km}$ dari Halte Maswati, dengan komoditas karet dan the (Ismet, 1970). Kemudian dalam arsip kolonial disebutkan bahwa:

Districten Radjamandala, Porceelen Maswati I - IV, Cultuurmaatschappij "Maswati", o., B.P. Warnsinek, a., ondernemers en erkende administrateur G.J. Eschauzier, o., E.H. Verstege, a., Uitgestrektheid van de porceelen in bouws (500 vierkante roeden) 483, 525, 242, 392; Datum van inschrijving van het erfpachtsrecht in the openbare registers 16 Juni 1899; Aard der geteelde production Koffie (Regeering Alamanaks voor Nederlandsch-Indie, 1901; 1902). 


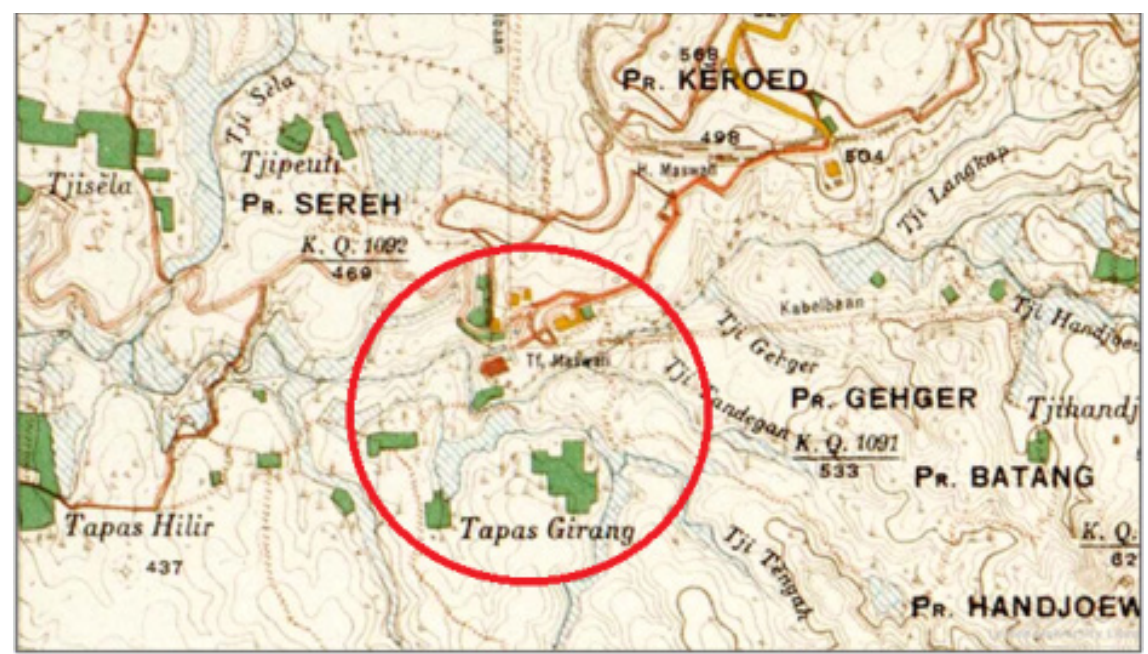

Gambar 8. Peta Topografi Kawasan Emplasemen Maswati (Sumber: Peta topografi Blad $31 \mathrm{~h}$ JAVA. Res. Pr. Regentschappen 1918. Dutch Colonial Maps, Leiden University Library. Laporan Penelitian Arkeologi 2018).

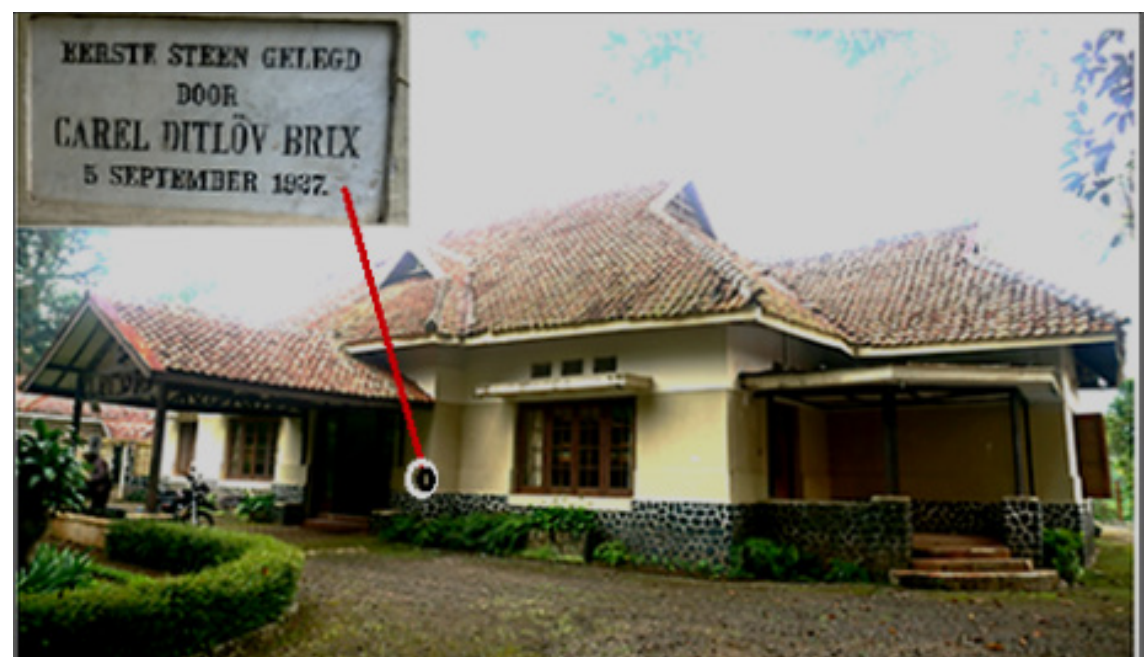

Gambar 9. Lokasi Prasasti Perkebunan Maswati di dinding muka bekas Gedung Pusdiklat Teh Perkebunan Panglejar di Emplasemen Maswati 2 (Sumber: Dokumen Balai Arkeologi Jawa Barat, 2018. Modifikasi oleh Lia Nuralia, 2020).

Berdasarkan keterangan pada arsip kolonial tersebut, Kebun Maswati sudah berdiri sejak tahun 1899, terdiri dari Maswati I sampai Maswati IV, dan komoditas awal yang diproduksi adalah kopi. Kemudian berdasarkan informasi yang diperoleh dari peta topografi lama Blad 31 h JAVA. Res. Pr. Regentschappen 1918 (Gambar 8), di Kebun Maswati sudah berdiri pabrik teh ( $T f=$ theefabriek), menunjukkan di tahun 1918 produksi teh sudah menggantikan kopi. Pada saat pendirian rumah ADM Maswati tahun 1927, kemungkinan produksi teh sudah beralih ke produksi karet atau beriringan dengan produksi karet. Puncak keemasan produksi teh di Hindia Belanda sudah tergantikan karet, ketika mendekati zaman malaise 1930 (O’Malley, 1988).

Pergantian dan peralihan komoditas ekspor perkebunan besar di masa Hindia Belanda tersebut, menunjukkan bukti bahwa permintaan barang dari luar negeri terus mengalami fluktuasi. Para pengusaha perkebunan tidak mau menanggung rugi, sehingga produksi komoditas ekspor disesuaikan dengan permintaan pasar. Ada kesinambungan 
produksi dengan bertambahnya komoditas baru atau pergantian komoditas tanaman. Kopi sudah berganti menjadi kina dan teh, serta sebagai komoditas unggulan lainnya.

Proses perubahan tersebut seolah berulang dan kembali ke titik awal. Seperti yang terjadi sekarang ini, kopi mulai ditanam kembali dan menjadi produksi unggulan setelah tanaman teh dan karet ${ }^{9}$. Sebelum karet, kina, dan teh, tanaman kopi pernah berjaya dan menjadi komoditas unggulan di wilayah Priangan (Jawa Barat). Pada tahap awal pemerintah Belanda membuka perkebunan kopi pada awal abad ke-18, di pedalaman Batavia dan dataran tinggi Priangan. Preangerstelsel sebagai Cultuurstelsel khusus Priangan, yang mengatur penanaman kopi di Priangan dipertahankan lebih lama, sedangkan Cultuurstelsel atau sistem penanaman secara paksa di daerah-daerah lain di Hindia Belanda ketika itu sudah dicabut. Setelah ditiadakannya sistem tanam paksa, pihak pengusaha swasta memiliki hak guna usaha dan tanah-tanah milik petani dibebaskan dari tanaman wajib (Breman, 2014: 61). UU Gula dan UU Agraria mulai diterapkan pada tahun 1870, ketika memasuki era Liberal (21 Juli, Staatsblad 136; 9 April 1870, Staatsblad 55; Koninklijk Besluit 20 Juli 1870, Staatsblad 118), berisi kebebasan berusaha dan perlindungan tanah milik pribumi, yaitu tanah milik pribumi tersebut tidak bisa dijualbelikan. Akan tetapi, pada kenyataannya keadaan pribumi tetap dalam kondisi tidak menguntungkan (Kartodirdjo \& Suryo, 1991)

Khusus Preangerstelsel tetap dipertahankan di era Liberal (1870-1900) sampai zaman Politik Etis (1901) (Kartodirdjo, 1990), mengingat keuntungan besar yang diperoleh dari kebijakan tersebut. Wilayah Priangan menjadi lokasi sangat strategis dan menguntungkan sejak zaman VOC (Vereenigde Oost Indische Compagnie) sampai Pemerintah Hindia Belanda, terutama setelah didirikan perkebunan besar (Boomgaard, 2004: 64). Selanjutnya berkembang ke daerah-daerah lain, di Pulau Jawa dan luar Jawa, dengan beragam jenis tanaman komoditas ekspor dunia. Pada abad ke-19 hingga awal abad ke-20 adalah puncak kejayaan perkebunan besar swasta asing di Hindia Belanda.

\section{Peta Lama Kolonial Perkebunan Rajamandala}

Artefak kolonial perkebunan di Kebun Afdeling Rajamandala berupa pelat cetak peta Kebun Rajamandala lama (Kaart Der Onderneming Radjamandala). Menurut Asep Abdul Aziz, pelat cetak peta lama tersebut sudah ada di lemari Kantor Afdeling Rajamandala 1, sejak dia bertugas di Rajamandala. ${ }^{10}$ Letak kantor afdeling merupakan lokasi lama Onderneming Radjamandala (Tjipeureudeuj) (Gambar 10), N.V. Landb., Mij. Radjamandala Djakarta, $\pm 2 \mathrm{~km}$ dari Halte Rajamandala, pinggir jalan raya dari Cianjur ke Bandung, dengan produksi teh dan karet (Ismet, 1970: 130). Sekarang Afdeling Rajamandala 1 Perkebunan Panglejar (Gambar 11), Kampung Cipeureudeuy, Desa Rajamandala Kulon, Kecamatan Cipatat, Kabupaten Bandung Barat (Nuralia, 2018).

\footnotetext{
9 Wawancara dengan Dedi Kusramdani, Administratur/Manajer Perkebunan Kertamanah, Tahun 2019.

${ }^{10}$ Wawancara dengan Asep Abdul Aziz, Asisten Afdeling Rajamandala 1 Perkebunan Panglejar (Rajamandala 1, April 2018).
} 


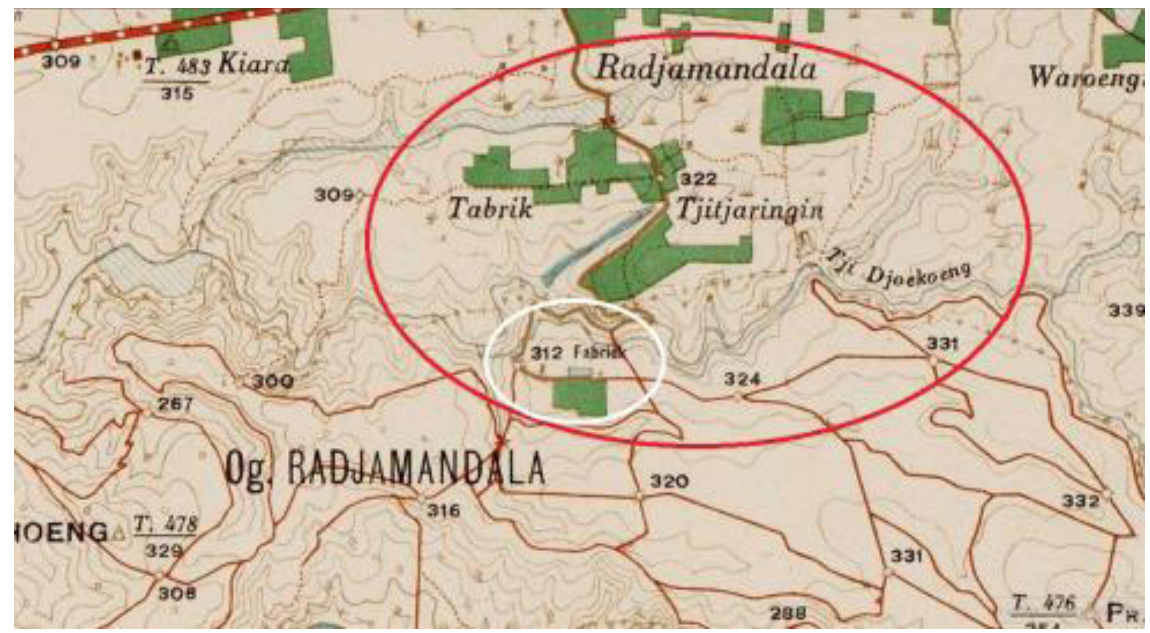

Gambar 10. Kebun Rajamandala dalam Peta Topgrafi lama (Sumber: Peta topografi Blad 31 d JAVA Resn Batavia en Pr. Regentschappen 1918. Dutch Colonial Maps, Leiden University Library).
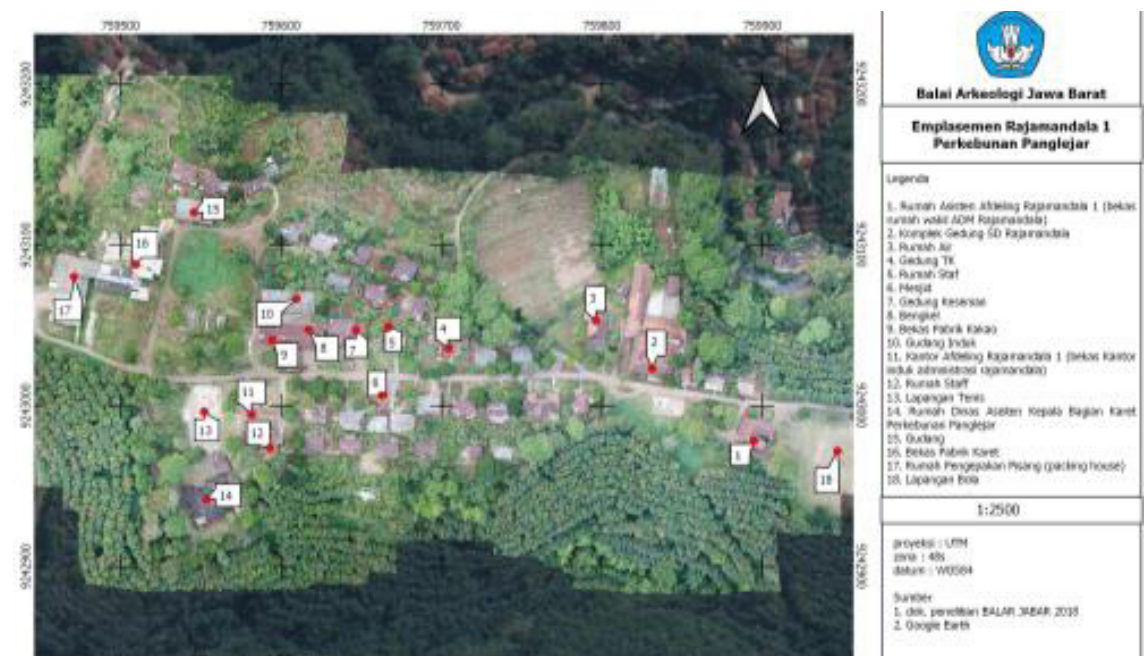

Gambar 11. Lokasi Artefak Perkebunan Rajamandala di dalam Gedung Kantor Afdeling Rajamandala 1 Perkebunan Panglejar (11) (Sumber: Dokumen Penelitian Arkeologi 2018. Modifikasi Lia Nuralia dan Azhar Rachman 2020).

Peta lama perkebunan Rajamandala "Kaart Der Onderneming Radjamandala" berbentuk persegi panjang dari bahan aluminium dengan dasar tatakan berbahan kayu olahan (hardboard) (Gambar 12). Pelat cetak peta lama tersebut kemudian digambar ulang (Gambar 13), sehingga memudahkan membaca dan menuliskan keterangan di peta tersebut. 


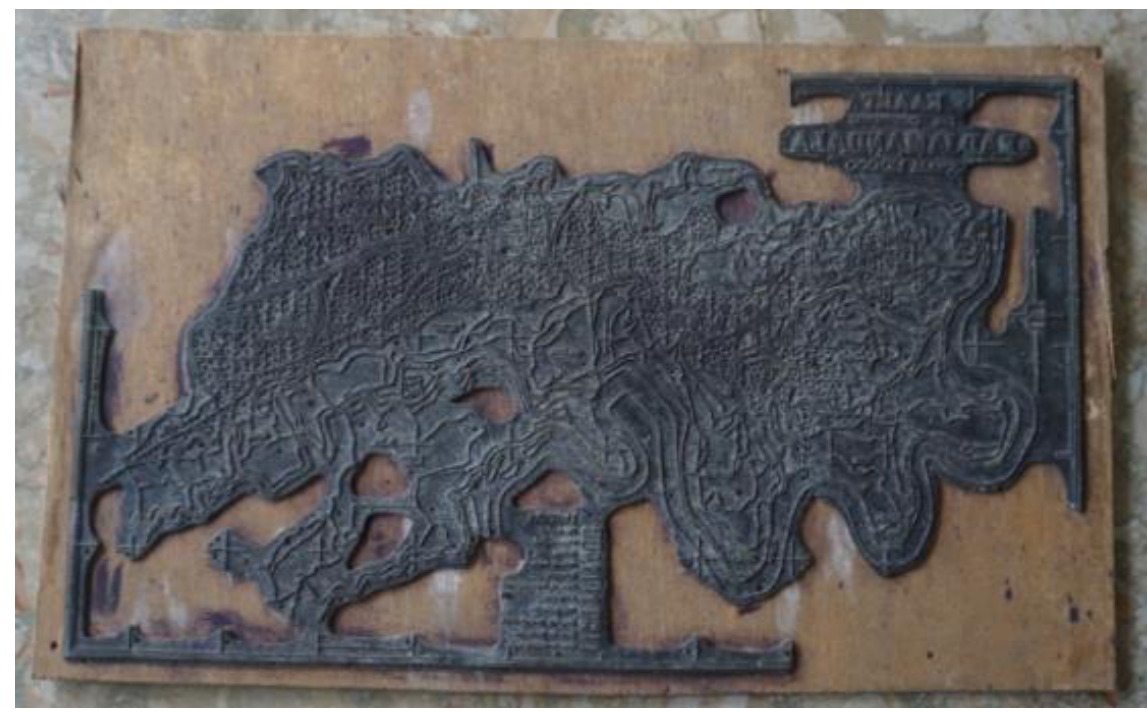

Gambar 12. Pelat Cetak Peta Lama Kebun Rajamandala (Kaart Der Onderneming Radjamandala (Sumber: Kantor Afdeling Rajamandala 1).

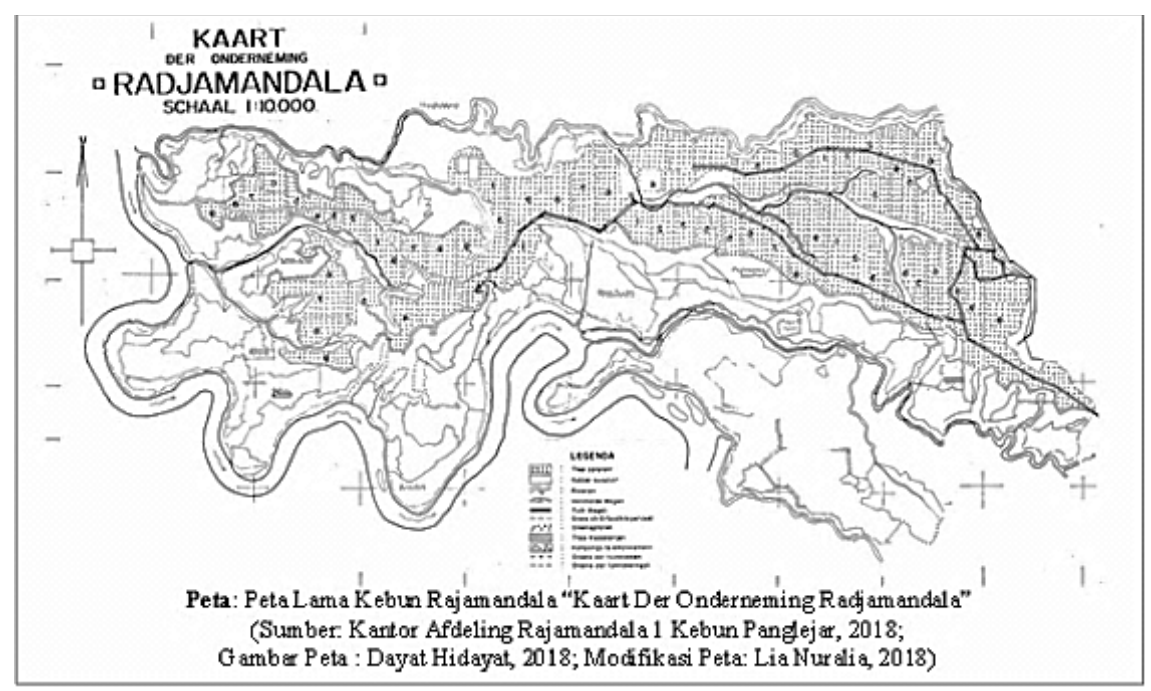

Gambar 13. Gambar Ulang Pelat Cetak Peta Lama Kebun Rajamandala (Gambar oleh Dayat Hidayat; Modifikasi oleh Lia Nuralia, 2018. Sumber: Balai Arkeologi Jawa Barat, 2018).

Berikut tulisan yang tertera di pelat cetak peta lama "Kaart Der Onderneming Radjamandala". Keterangan peta berbahasa Belanda dan beraksara Latin yang diterjemahkan secara bebas ke dalam Bahasa Indonesia (Onderneming Radjamandala, n.d.).

\section{KAART DER ONDERNEMING RADJAMANDALA, SCHAAL 1: 10.000, LEGENDA:}

1. Thee aanplant

2. Rubber aanplant

3. Rivieren

4. Vercharde Wegen

5. Tuin Wegen

6. $\quad$ Grens ch Erfpachteperceel

7. Grenspilaren 
8. Thee Kweekerijen

9. Kamponge te emplacement

10. Grens der tuinblokken

11. Grens der tuinindeelingen

Peta Perusahaan (Perkebunan) Radjamandala, Skala 1: 10.000, Legenda:

1. Kebun (tanaman) teh

2. Kebun (tanaman) karet

3. Sungai

4. Jalan beraspal (jalan perkebunan)

5. Tempat Timbang atau Jalan Kebun

6. Perbatasan petak prasarana (blok permukiman emplasemen)

7. Pilar batas

8. Budidaya Teh

9. Kampung emplasemen

Perbatasan blok kebun

10. Perbatasan jalan kebun

Keterangan dalam peta kebun Rajamandala lama tersebut menjelaskan tentang wilayah kebun dan emplasemen Rajamandala di masa lalu. Tidak diketahui tahun berapa peta tersebut dibuat dan tidak ada penjelasan lebih lanjut tentang kondisi Kebun Rajamndala ketika itu, tetapi dapat diketahui bahwa Kebun Rajamandala dahulu memiliki komoditas teh dan karet. Kenyataan di lapangan di tahun 2018, kebun teh sudah tidak ada lagi, hanya ada kebun karet. Proses produksi karet juga hanya menyediakan bahan baku latex, sedangkan pengolahan dilakukan di Pabrik Karet Maswati ${ }^{11}$. Pabrik Karet Maswati sekarang ini (2020) sudah tidak beroperasi, terkait adanya proyek seperti yang sudah dijelaskan ${ }^{12}$. Dengan demikian, untuk produksi teh di pabrik dan di Kebun Rajamandala sekarang ini sudah tidak ada lagi bekas-bekasnya.

Arsip kolonial tentang Perkebunan Rajamandala menyajikan dua tanah persil yang bernama Rajamandala sebagai berikut.

Districten Soemedang, Porceelen Radjamandala, ondernemers en erkende administrateur A.J. Ovink, Mr. C.A.Henny en L.H. Du Peron, o., A.J.Ovink, a., (H.Th. van Heeking Clenbrabder en K.G. baron van Reede van Oudshoorn, a.); Uitgestrektheid van de porceelen in bouws (500 vierkante roeden) 89, Datum van inschrijving van het erfpachtsrecht in the openbare registers 28 Juni 1888, Aard der geteelde production Thee en Kina (Regeering Alamanaks voor NederlandschIndie, 1901; 1902: 358-359).

Districten Radjamandala, Porceelen Radjamandala en Radjamandala I, Cultuurmaatschappij “Pangledjar", o., D.C. Boutmy, a., ondernemers en erkende administrateur G.J. Eschauzier, o., E.H. Verstege, a., Uitgestrektheid van de porceelen in bouws (500 vierkante roeden) 378, 124, Datum van inschrijving van

\footnotetext{
${ }^{11}$ Wawancara dengan Jimmy Permana, Asisten Kepala Bagian Karet Perkebunan Panglejar, Maret 2018.

12 Wawancara dengan Asep Abdul Aziz, Asisten Afdeling Rajamandala 1 Perkebunan Panglejar, Maret 2020 .
} 
het erfpachtsrecht in the openbare registers 18 Februari 1893 en 12 Januari 1897, Aard der geteelde production Koffie (Regeering Alamanaks voor NederlandschIndie, 1901; 1902).

Ada dua persil kebun bernama Rajamandala, tetapi melihat dari keberadaannya di distrik yang berbeda, yaitu Distrik Sumedang dan Distrik Rajamandala, maka persil Kebun Rajamadala dalam kajian ini adalah Kebun Rajamandala di Distrik Rajamandala. Keadaan ini juga sesuai dengan informasi dari peta dan hasil observasi langsung ke lapangan (2018).

Berdasarkan arsip kolonial tersebut, Kebun Rajamandala sebagai tanah persil atau erfpacht sudah tercatat dalam registrasi Pemerintah Belanda sejak tahun 1893, kemudian persil Rajamandala 1 tahun 1897. Komoditas awal adalah tanaman kopi (Regeering Almanaks 1901/1902), kemudian menanam teh dan karet seperti yang tertulis dalam keterangan Peta Lama Kebun Rajamandala tersebut (Thee aanplant; Rubber aanplant). Dengan demikian, sama halnya dengan kebun Panglejar dan Kebun Maswati, mengalami pergantian komoditas tanaman yang disesuaikan dengan kebutuhan pasar internasional.

\section{Arti dan Arah Sejarah Artefak Kolonial Perkebunan}

Artefak kolonial perkebunan berupa prasasti pendirian suatu bangunan dan peta lama wilayah kebun, merupakan benda yang memiliki arti khusus dan menjadi petunjuk arah sejarah perkebunan. Temuan artefak dengan informasi yang terkadung di dalamnya mengandung arti bahwa telah terjadi peristiwa penting di masa lalu. Kemudian artefak tersebut juga memberi petunjuk untuk mencari informasi lain (arsip) sebagai pelengkap penjelasan (Tabel 1). Informasi inskripsi prasasti dan peta lama sifatnya terbatas. Petunjuk artefak tersebut membuka bukti kesejarahan baru, yang menambah dan memperkuat penjelasan, melalui arsip kolonial yang diperoleh.

Tabel 1. Artefak Kolonial Perkebunan Panglejar, Maswati, dan Rajamandala

\begin{tabular}{|c|c|c|c|c|c|c|}
\hline No. & Nama Artefak & Bentuk & Fungsi & & Bahan & Keterangan \\
\hline 1. & $\begin{array}{l}\text { Prasasti Pabrik } \\
\text { Teh Panglejar } \\
\text { lama }\end{array}$ & Persegi panjang & $\begin{array}{l}\text { Informasi } \\
\text { dokumentasi } \\
\text { sejarah }\end{array}$ & dan & $\begin{array}{l}\text { Batu marmer, } \\
\text { warna abu-abu } \\
\text { tua motif }\end{array}$ & $\begin{array}{l}\text { Menunjukkan tahun } \\
\text { pendirian, peresmian, dan } \\
\text { pejabat ADM }\end{array}$ \\
\hline 2. & $\begin{array}{l}\text { Prasasti Rumah } \\
\text { ADM Kebun } \\
\text { Maswati lama }\end{array}$ & Persegi panjang & $\begin{array}{l}\text { Informasi } \\
\text { dokumentasi } \\
\text { sejarah }\end{array}$ & dan & $\begin{array}{l}\text { Batu marmer, } \\
\text { putih polos }\end{array}$ & $\begin{array}{l}\text { Menunjukkan tahun } \\
\text { pendirian dan yang } \\
\text { meletak batu pertamanya. }\end{array}$ \\
\hline 3. & $\begin{array}{l}\text { Peta Kebun } \\
\text { Rajamandala } \\
\text { lama }\end{array}$ & Persegi panjang & $\begin{array}{l}\text { Informasi } \\
\text { dokumentasi } \\
\text { sejarah }\end{array}$ & dan & $\begin{array}{l}\text { Seng dan kayu } \\
\text { olahan/partikel }\end{array}$ & $\begin{array}{l}\text { Menunjukkan lahan } \\
\text { kebun dan tanaman } \\
\text { komoditas utama kebun }\end{array}$ \\
\hline
\end{tabular}

Secara fisik artefak kolonial perkebunan yang ditemukan menggambarkan penggunaan bahan dan pemanfaatan fungsi tertentu. Bahan prasasti Pabrik Panglejar lama yang dipahatkan di dinding Gedung IHT berupa batu marmer abu-abu tua bercorak, yang dibentuk persegi panjang, dengan pahatan tulisan menggunakan teknologi pahat sederhana. Adapun fungsinya adalah untuk memenuhi kebutuhan praktis, berita acara pendirian Gedung Pabrik Teh Panglejar lama. Pabrik teh sebagai bangunan produksi utama menjadi bangunan penting yang diresmikan pendiriannya oleh orang penting 
dalam perusahaan. Keberadaan pabrik merupakan simbol kemajuan perusahaan dengan tingginya produktivitas yang dihasilkan. Berdasarkan arsip kolonial yang ditemukan, penjelasan prasasti menjadi lengkap dan masuk akal, memberi arah yang benar mengenai sejarah perkebunan dan kesinambungannya sampai sekarang.

Keterangan prasasti dan arsip yang berkaitan menunjukkan bahwa peresmian suatu bangunan dilakukan oleh pejabat yang berwenang, dan atau yang mewakilinya. Peran penting Marianne Jeannette van Hillegondsberg sebagai orang yang meresmikan pendirian pabrik, dimungkinkan posisinya sebagai anak administratur atau diwakilkan olehnya, atau bisa juga bahwa ketika itu ayahnya sudah pensiun dan dia menggantikan posisi ayahnya sebagai administratur. Kemudian disebutkan bahwa pada tahun 1925 adalah peletakan batu pertama pendirian pabrik teh Panglejar. Kemungkinan besar adalah peletakan batu pertama pendirian kembali pabrik teh Panglejar, sesudah rusak karena mengalami kebakaran pada tahun yang sama. Kemungkinan ini berdasarkan peta topografi lama yang memunculkan theefabriek di Panglejar dalam peta tahun 1918-an. Selain itu, arsip kolonial juga memberi informasi tentang pendirian pertama kali kebun Panglejar pada tahun 1893. Apakah pada tahun 1893 sudah dibangun pabrik atau baru didirikan beberapa tahun kemudian, belum ada informasi yang lebih detail. Dengan demikian, pabrik teh Panglejar yang pertama kali didirikan jauh sebelum tahun 1925 dan kemungkinan juga sebelum tahun 1918.

Prasasti pendirian rumah dinas Administratur Perkebunan Maswati (Gedung Pusdiklat Panglejar), secara fisik menggunakan bahan batu marmer berwarna putih abu-abu, berbentuk persegi panjang. Tulisan yang dipahatkan menggunakan teknologi sederhana. Keterangan yang diperoleh bersifat sangat terbatas, hanya nama peletak batu pertama pendirian gdeung dan angka tahun pendirian. Keterbatasan informasi tersebut memicu pencarian data arsip, sehingga diperoleh keterangan yang lebih lengkap. Arsip kolonial tentang Kebun Maswati di masa lalu ditunjukkan oleh peta topografi lama dan keterangan dari Regeering Almanaks.

Peta topografi lama tahun 1918 menunjukkan keberadaan lokasi Pabrik Teh Maswati (Tf=Theefabriek). Kemudian tertulis dalam Regeering Almanaks 1893 bahwa Onderneming Maswati yang telah berdiri tahun 1899 memproduksi tanaman kopi (Regeering Alamanaks voor Nederlandsch-Indie, 1893). Kemungkinan tanaman kopi diganti dengan teh dan karet sesuai dengan permintaan pasar internasional. Ketika penelitian lapangan tahun 2018, Kebun Maswati menanam teh dan karet serta masih memproduksi karet di pabrik sendiri, sedangkan produksi teh sudah dialihkan ke Pabrik Panglejar. Jejak pabrik teh Maswati ketika itu sudah tidak ditemukan.

Peta lama Kebun Rajamandala secara fisik terbuat dari bahan aluminium dan kayu olahan (hardboard). Penjelasan dari peta menunjukkan adanya batas wilayah yang jelas, seperti wilayah emplasemen permukiman, wilayah kebun teh, wilayah kebun karet, dan lain sebagainya. Kebun teh di Kebun Rajamandala sudah tidak ada, yang ada hanya kebun karet dan bekas tanaman kakao. Selain produksi teh dan karet, Pabrik Rajamandala juga pernah memproduksi kakao dan jejak pabrik kakao masih ada (2018). Kebun Rajamadala juga memiliki produksi pisang dengan adanya pabrik pengepakan pisang (housekeeping), yang bangunannya merupakan pabrik baru tetapi berdiri di lahan lama bekas lahan pabrik lama. Lahan pabrik pengepakan pisang tersebut diperkirakan sebagai bekas pabrik teh dan pabrik karet lama Kebun Rajamandala lama. 


\section{SIMPULAN}

Keberadaan artefak kolonial perkebunan memberi arti dan arah sejarah. Artefak tersebut memberi informasi tentang sejarah pendirian bangunan dan sejarah perkebunan itu sendiri. Selain itu, juga memberi informasi tentang fungsi bangunan dan orang-orang penting yang terlibat di dalamnya. Keberadaan artefak juga memberi arah untuk pencarian informasi tambahan yang melengkapi dan memperkuat berupa arsip kolonial.

Prasasti Pabrik Teh Panglejar lama dan arsip kolonial, memberi informasi kesejarahan, yaitu: (1) Pabrik Teh Panglejar lama dididirkan sebelum tahun 1925, (2) Tahun 1925 pabrik didirikan kembali dan peletakan batu pertama dilakukan oleh Marianne Jannete van Hillegonberg (anak dari Jan Frederick van Hillegonberg), (3) Jan Frederick van Hillegonberg adalah administratur yang menjabat ketika itu, (4) Marianne Jannete van Hillegonberg adalah anak Administratur Jan Frederick van Hillegonberg, dan (5) Jan Frederick van Hillegonberg adalah seorang Belanda yang lahir tahun 1890 dan meninggal dunia tanggal 9 Maret 1945, karena sakit malaria selama berada di kamp interniran Jepang, serta dimakamkan di pemakaman Simpang Ampat Sumatera.

Prasasti rumah ADM Kebun Maswati lama memberi keterangan penting, yaitu: (1) sebagai bekas Rumah Dinas Administratur Perkebunan Maswati, yang sudah berdiri tanggal 5 September 1927 dan, (2) peletakan batu pertama dilakukan oleh Carel Ditlov Brix. Tanaman dan produksi Kebun Maswati awalnya adalah kopi, kemudian produksi teh dan karet. Sekarang ini bangunan sudah rusak dan dibiarkan begitu saja tanpa ada perawatan dan kemungkinan tidak dipertahankan sebagai bangunan cagar budaya.

Peta lama kolonial Kebun Rajamandala memberi informasi kesejarahan, yaitu: (1) tanaman komoditas teh dan karet, (2) berada di wilayah dengan aliran sungai, (3) jalan perkebunan sudah beraspal dan merupakan jalan kebun sendiri, (4) terdapat blok lahan permukiman emplasemen, (5) memiliki kebun budidaya teh, (6) batas permukiman dan lahan kebun sudah ada pilar batas yang tegas dan jelas, dan (7) kebun terdiri dari blokblok kebun.

\section{UCAPAN TERIMA KASIH}

Terima kasih kepada Direksi PTPN VIII yang telah memberi izin melakukan penelitian di kebun tahun 2018; terimakasih kepada Administratur, Bagian Umum, Petugas Tanaman, Asisten Afdeling Panglejar 1A/1B, Asisten Afdeling Maswati, Asisten Kepala Bagian Karet, Asisten Afdeling Rajamandala 1 Perkebunan Panglejar; terimakasih kepada Kepala Produksi IHT Sub Unit Panglejar PTPN VIII, yang telah bersedia diwawancara dan telah membantu observasi selama di lapangan; terimakasih kepada teman-teman tim peneliti perkebunan tahun 2018, yang telah memberikan hasil lapangan harian dengan baik; terima kasih juga kepada sahabat Hans Boers, yang telah memberi informasi kesejarahan dan mengirim file (dokumen arsip Belanda) tahun 2020.

\section{DAFTAR PUSTAKA}

Boomgaard, P. (2004). Anak Jajahan Belanda, Sejarah Sosial dan Ekonomi Jawa 17951880. Terjemahan Monique Soesman, Keosalah Soebagyo Toer. Jakarta: KITLVJakarta dan Djambatan.

Breman, J. (2014). Keuntungan Kolonial Dari Kerja Paksa: Sistem Priangan dari Tanam Paksa Kopi di Jawa 1720-1870. Jakarta: Yayasan Obor Indonesia. 
Cambridge Dictionary. (n.d.). Cambridge Academic Content Dictionary. Cambridge University Press.

Cassela, E. C. (2005). Social Workers: New Diretions in Industrial Archaeology. In E. C. C. and J. Symonds (Ed.), Industrial Archaeology : Future Directions (hal. 3-32). USA: Springer Science and Business Media Inc.

Geplaatst door Coordinator Archief, Oorlogsgravenstichting op 12 Januari 2015. (n.d.). Den Haag: Gehetna van het archief.

Inventaris van het archief, No. 094f, Inventaris No: 4577. Dossier: 4322. Organisatie: NIOD Onstituut Voor Oorlogs-, Holocaust-en Genocidestudies: 40. (n.d.). Den Haag: Gehetna van het archief Den Haag.

Inventaris van het archief van het Fonds/Belindo: Thee cultuur maatschappaij Pangheotan een Diverse Andere Cultuur maatschappijen, 1894-1875, Door J.A.A.Bervoets. (1994). National Archief, Den Haag. Diambil dari http://www.gahetna.nl/collectie/ archief/pdf/NL-HaNA_2.20.37.11.ead.pdf. 2017

Ismet. (1970). Daftar-Tanah Perkebunan ${ }^{2}$ Di Indonesia (The List Of Estates Throughout Indonesia). Bandung: Biro Sinar C.V.

Kartodirdjo, S. (1990). Pengantar Sejarah Indonesia Baru: Sejarah Pergerakan Nasional Dari Kolonialisme Sampai Nasionalisme. Jilid 2. Jakarta: Gramedia.

Kartodirdjo, S., \& Suryo, D. (1991). Sejarah Perkebunan di Indonesia: Kajian Sosial Ekonomi. YOGYAKARTA: Aditya Media.

Ministerie van Onderwijs, Cultuur en Wetenschap, Nummer Archiefinventaris: 2.20.37.11. (n.d.). National Archief.

Nuralia, L. (2018). Bangunan dan Produksi Perkebunan Panglejar dan Bukit UnggulSukawana Kabupaten Bandung Barat, Provinsi Jawa Barat. Bandung.

O’Malley, W. J. (1988). Perkebunan 1830-1940: Ikhtisar. In A. W. Anne Booth, William J. O’Malley (Ed.), Sejarah Ekonomi Indonesia (hal. 136). Jakarta: LP3ES.

Onderneming Radjamandala. (n.d.). Kaart Der Onderneming Radjamandala. Bandung Barat: Kantor Afdeling Rajamandala 1 Perkebunan Panglejar.

Palmer, M. (2005). Industrial Archaelogy: Constructing a Framework of Inference. In E. C. C. and J. Symonds (Ed.), Industrial Archaeologi: Future Directions, Contributions to Global Historical Archaeology. New York: Springer Science and Business Me.

Persoonlijkheden In Het Koninkrijk Der Nederlanden In Woord en Beeld. Nederlanders en Hun Werk, Door DR. N. Japikse. (1938). Koninklijk Huisarchief Te'sGravenhage, van Holkema Warendorf N.V. Diambil dari http://resources.huygens. knaw.nl/retroboeken/persoonlijkheden/\#source $=1 \&$ page $=217 \&$ accessor $=$ toc

Puslitbang Arkenas. (2008). Metode Penelitian Arkeologi (Cetakan ke). Jakarta: Pusat Penelitian dan Pengembangan Arkeologi Nasional, Departemen Kebudayaan dan Pariwisata.

Regeering Alamanaks voor Nederlandsch-Indie. (1893). Batavia: Landsdrukkerj. 
Regeering Alamanaks voor Nederlandsch-Indie. (1901). Batavia: Landsdrukkerj.

Regeering Alamanaks voor Nederlandsch-Indie. (1902). Batavia: Batavia.

Wardini, C., Permadi, G., Muhammad Iqbal, \& Widianti, N. (2010). Dari Bumi Pasundan Menembus Dunia, Perjalanan Panjang PT Perkebunan Nusantara VIII. Bandung: PT Perkebunan Nusantara VIII. 